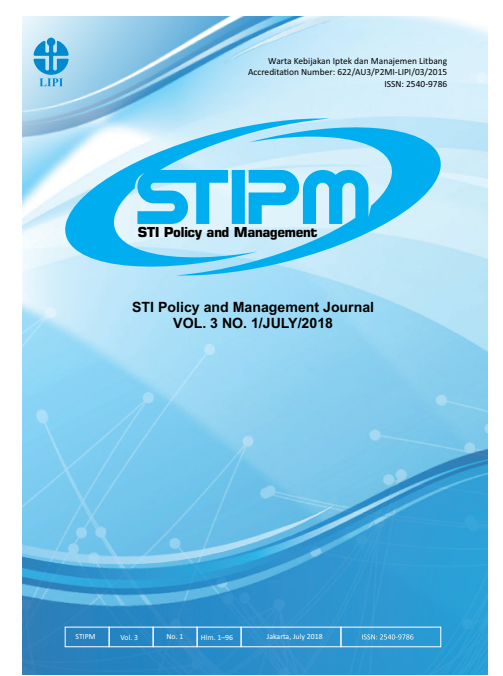

Journal of STI Policy and Management

Publication details, including instructions for authors and subscription information: http://www.stipmjournal.org/

\title{
The Value Chain Analysis to Support Industrial Cluster Development of Oil Palm-Cattle Integration in Pelalawan Regency
}

Kristiana, Zulfika Satria Kusharsanto, Ramos Hutapea

The Center for Technopreneurship and Industrial Cluster, BPPT

Version of record first published: 15 July 2018

To cite this article: Kristiana, Kusharsanto, Z.S., and Hutape, R. (2018). The Value Chain Analysis to Support Industrial Cluster Development of Oil Palm-Cattle Integration in Pelalawan Regency. Journal of STI Policy and Management, 3(1), 81-96

To link to this article: http://dx.doi.org/10.14203/STIPM.2017.111

ISSN 2540-9786 (Print); ISSN 2502-5996 (online)

Accreditation Number: 21/E/KPT/2018

Full terms and conditions of use: https://creativecommons.org/licenses/by-nc-sa/4.0/

You are free to:

- Share : copy and redistribute the material in any medium or format

- Adapt : remix, transform, and build upon the material

- The licensor cannot revoke these freedoms as long as you follow the license terms.

Under the following terms: Attribution - You must give appropriate credit, provide a link to the license, and indicate if changes were made. You may do so in any reasonable manner, but not in any way that suggests the licensor endorses you or your use.

$\$$ NonCommercial - You may not use the material for commercial purposes.

(3) ShareAlike - If you remix, transform, or build upon the material, you must distribute your contributions under the same license as the original.

No additional restrictions - You may not apply legal terms or technological measures that legally restrict others from doing anything the license permits.

Notices:

- You do not have to comply with the license for elements of the material in the public domain or where your use is permitted by an applicable exception or limitation.

- No warranties are given. The license may not give you all of the permissions necessary for your intended use. For example, other rights such as publicity, privacy, or moral rights may limit how you use the material.

- If you copy the dataset merely to extract the uncopyrightable data elements would not need permission to do so. However, if you republish the full dataset or using the copyrightable data layers require a permission from PAPPIPTEK-LIPI. 


\title{
JOURNAL OF SCIENCE, TECHNOLOGY, AND INNOVATION POLICY AND MANAGEMENT (STIPM JOURNAL), Volume 03, Number 01, July 2018
}

\author{
FOREWORD by EDITOR-in-CHIEF
}

We are glad to announce that the journal of Science, Technology, \& Innovation Policy and Management (STIPM Journal) Vol 3, No. 1, July, 2018 is ready for public reading and views. The journal itself focus on STI policy and management.

The aim of this issue is to combine the various perspectives of R\&D management and STI policy. Original papers as well as case studies-based research are presented to the readers.

STIPM Journal is an online research journal managed by the Center for Science and Technology Development Studies, Indonesian Institute of Sciences (PAPPIPTEK-LIPI). This journal is a blind peer reviewed journal, which provides free access to research thoughts, innovation, and original discoveries that are needed mostly by the research scholars. In this edition, the STIPM Journal contains six articles dealing with science, technology and innovation policy and management written by scholars from Japan, Thailand, India and Indonesia.

The first article, entitled India's science, technology and innovation policy: Choices for course corection with lessons learned from China by G.D. Sandhya. In this paper, an attempt has been made to look at how comprehensive India's STI policies with regard to policy components; a roadmap; and strategies for execution and boldness in terms of identifying and recognising the failures and recommend major structural changes. What is intended is to understand the relationship between the domain of S\&T policy and expected outcomes; the mismatch between the policy expectations and outcomes. An attempt is being made to identify possibility for correction by taking lessons from other economies, such as China.

Second article were written by Wati Hermawati, et al., entitled Outcome and impact based evaluation of research program implementation: A case of Indonesian public research institute. This article relates to outcome and impact based evaluation (OIBE) of a research program implementation at an Indonesian public research institute (PRI) 'A'. The major funding for PRIs in Indonesia comes from government. It is very essential, therefore, for various parties including policy makers to be informed about meaningful and relevant evaluation of the outcome and impact of such PRI to the welfare of the people, to technology development and innovation, and to the policy improvements in significant ways.

Hidenori Shigeno, et al., presents the third article, Internal innovation capability and ICT use in the innovation process from the view of connectivity in Japanese SMEs. This article discusses how internal innovation capability such as the technological level and R\&D (Research and Development) contributes to the innovation and how it is promoted by ICT use. Using the survey data of about 650 SMEs (Small Medium Enterprise) from all over Japan, this study constructs two models with ICT or without ICT and focuses on how SEMs (Structural Equation Modeling) obtain information from external linkages and the role of ICT in the innovation process 
The effect of team diversity in cross-functional teams for enhancing research commercialization: An experience of Thai public research institute is an article presented by Warangkana Punyakornwong. This article discusses the effect of team diversity and institutional factors in terms of top management support and incentive system on the number of license agreements in the context of the National Science and Technology Development Agency (NSTDA) in Thailand.

The fifth article entitled $A$ contextual scientometric analysis of Indonesian biomedicine: Mapping the potential of basic research downstreaming is presented by Ria Hardiyati, et al. The article discusses how to obtain a rich contextual overview of the development of biomedicine research in Indonesia, for example in the context of the down-streaming potential of research publications. The results of text data processing using a computational model and bibliometric analysis will provide a richer contextual picture as a proxy to reveal the potential for down-streaming of basic research.

Final article was compiled by Kristiana, et al., with the title The value chain analysis to support industrial cluster development of oil palm-cattle integration in Pelalawan Regency, Indonesia. This article discusses the value chain of oil palm-cattle integration proggram and to formulate reinforcement programs to develop cluster of oil palm-cattle integration with industrial cluster approaches. Among the five products from the oil palm-cattle integration program, the liquid organic fertilizer and solid manure are more profitable than the primary product of husbandry: the beef. Nonetheless, both products are highly dependent on the beef cattle existence. In other words, if the business of manure and liquid organic fertilizer are not profitable, the business of beef cattle will also fail.

In addition to all articles that presented in this volume, we also would like to thank the authors, editors, and reviewers who have worked very hard in this edition. We hope that all articles featured in this edition will be useful for the reader.

Jakarta, 16 July 2018

Editor-in-Chief 



\section{JOURNAL OF STI POLICY AND MANAGEMENT}

Volume 3, Number 1, July 2018

\section{LIST OF CONTENTS}

India's Science, Technology and Innovation Policy: Choices for Course Correction with Lessons Learned from China

G.D. Sandhya

Outcome and Impact Based Evaluation of Research Program Implementation: A Case of Indonesian Public Research Institute

Wati Hermawati, Saut Siahaan, Ishelina Rosaira Radot Manalu, and Agus Santoso

Internal Innovation Capability and ICT Use in the Innovation Process from the View of Connectivity in Japanese SMEs

Hidenori Shigeno, Taisuke Matsuzaki, and Masatsugu Tsuji

The Effect of Team Diversity on R\&D Licensing in the Thai Public Research Institute

Warangkana Punyakornwong

A Contextual Scientometric Analysis of Indonesian Biomedicine: Mapping the Potential of Basic Research Downstreaming

Ria Hardiyati, Irene Muflikh Nadhiroh, Tri Handayani, V.M. Mesnan Silalahi,

Rizka Rahmaida, and Mia Amelia.....

The Value Chain Analysis to Support Industrial Cluster Development of Oil Palm-Cattle Integration in Pelalawan Regency

Kristiana, Zulfika Satria Kusharsanto, Ramos Hutapea . 


\title{
The Value Chain Analysis to Support Industrial Cluster Development of Oil Palm-Cattle Integration in Pelalawan Regency
}

\author{
Kristiana, Zulfika Satria Kusharsanto, Ramos Hutapea \\ The Center for Technopreneurship and Industrial Cluster, BPPT \\ Building 720, PUSPIPTEK, Setu, Tangerang Selatan, Indonesia 15314
}

\begin{tabular}{l}
\hline ARTICLE INFO \\
\hline Article History: \\
Received : 31 January 2017 \\
Revised : 11 May 2018 \\
Accepted : 16 May 2018 \\
Available online : 15 July 2018 \\
\hline
\end{tabular}

Keywords:

Oil palm-cattle integration

Value chain

Value-added

Industrial cluster

\begin{abstract}
As a region with the largest oil palm plantations in Indonesia, Pelalawan Regency is highly potential for developing an oil palmcattle integration program. Pelalawan has implemented the program legitimated by Regent Decree Number KPTS./524/Disnak/2012/472 regarding Zoning Regulation on the development of Oil Palm-Cattle Integration. The program of oil palm-cattle integration itself has been the basis for the Decree of the Minister of Agriculture Number 105 Year 2014 regarding the Integration of Oil Palm Plantation and Beef Cattle Farming. Moreover, the integration system of oil palmcattle gives a lot of benefit to farmers, for example the utilization of manure as organic fertilizers could reduce farmer's expenses for chemical fertilizers and the cattle can be an asset for them. Products made from the integrated program are solid manure, liquid organic fertilizer, fodder, biogas, and beef. To improve the competitiveness of those activities, we can analyze the value chain which includes product design, inbound logistics, operations, outbound logistics, marketing, sales, services and supporting activities. By using a value chain analysis, this study aims to provide recommendations for strengthening programs which could be implemented to improve the value-added of the products.
\end{abstract}

C2018 PAPPIPTEK-LIPI All rights reserved

\section{INTRODUCTION}

Since 2010, the national beef self-sufficiency program has begun to strengthen the national food security, based on animal protein products. In 2014, national demand on beef was met by $30 \%$ import, while the government guidelines allow only 10\% per annum. Data in 2014 issued by the Ministry of Agriculture shows that the demand for beef was 653,982 ton or equal to

\footnotetext{
* Corresponding Author. +628122613025

E-mail: kristiana@bppt.go.id
}

$3,843,787$ cattle. Unfortunately, local supply was only $2,445,577$ cattle; therefore, deficit of beef was approximately 237,890 ton, or equal to 1.39 million cattle (Ministry of Agriculture, 2015). This reveals that the program of beef self-sufficiency has failed.

Since the policy of Revitalization of Agriculture, Fisheries and Forestry (RPPK) was launched by the President in 2004, the concept of oil palm-cattle integration has been adopted by the society (Gunawan, Sitompul, \& Manurung, 2004). In 2007, several local governments made 
the integration program as their featured program. Developing cattle farming by using the integration system in oil palm plantation is easier in local region due to the availability of enormous potential land. The idea of integrating beef-cattle with oil palm plantation is to give solution to land and fodder scarcity which has been the barrier to beef self-sufficiency program (Daryanto, 2011).

Pelalawan Regency is a region which has the largest oil palm plantation area in Indonesia. In 2012, the area of plantation was 378,161 Ha (BPS Kabupaten Pelalawan, 2013), which indicates that the program was running well. The regional government of Pelalawan implemented the integration program as their regional program by legitimating it with its Regent Decree. The program of oil palm-cattle integration itself has been the basis for the Decree of the Minister of Agriculture Number 105 Year 2014 regarding the Integration of Oil Palm Plantation and Beef Cattle Farming.

Regarding the potential of high national demand and followed by the existence of many resources, especially in Pelalawan, cattle farming development seems very promising. Some experts see that increasing competitiveness of cattle farming in the middle of oil palm plantation is a strategic program (Situmorang, Edwina, \& Maharani, 2015).

The business competitiveness can be analyzed with value chain analysis which consists of product design, inbound logistics, operations, outbound logistics, marketing, sales, services and support activities. A firm has competitive advantage if it can deliver product to consumers which is as good as their competitors' but with lower price, or the firm can provide products or services with higher price but still has good demand.

The term of value chain refers to a process for producing or providing products or services which begins with conceptual stage, then production stage until delivery to consumers and finally decay after being used (Kaplinsky, 1999; Kaplinsky \& Morris, 2001). The value chain can be set if all stakeholders within the chain work together to get the highest value in every step of the chain.
The concept of value chain encompasses organizational issues, strategy coordination and forced connection among stakeholders within the chain. It is important to understand that value chain analysis needs holistic investigation of stakeholders' relationship, such as things that unite them, information they share with each other, and how the relationship can change or become stronger.

Moreover, the idea of value chain is related to the concept of governance which makes social and environment researchers more interested in value chain analysis (ACIAR, 2012). For instance, the form and alteration of value chain can potentially depress natural resources, like water and soil, which can further cause soil degradation, destroy biodiversity or make pollution. The development of value chain can also affect social relations and traditional norms (Andri \& Stringer, 2010).

The above mentioned facts reveal the absence of assessment on effectiveness regarding value-added products of the integration program. Hence, this study aims to analyze value chain of each product and to formulate reinforcement programs to develop cluster of oil palm-cattle integration with industrial cluster approaches.

To elaborate properly, the structure of this study is arranged as follows: (1) introduction, which contains background and aims of the study; (2) theoretical framework about value-added, and value chain; (3) research method; (4) result and discussion which consist of the analysis of value chain and value-added of each product such as fodder, solid manure, liquid organic fertilizer, biogas, beef cattle and the comparison among all products; and (5) the conclusion where some important points are highlighted.

\section{CONCEPTUAL FRAMEWORK}

\section{A. Porter's Value Chain Approach}

Porter (1985) used the value chain framework to learn how a firm should position itself in the market and in the circle of other stakeholders such as raw material providers, buyers and competitors. The idea of competitive advantage of a business can be summarized as how a business can give 
consumers a product or service whose value is equal to competitors' product and with lower price (low budget strategy). Another option is to produce product or provide services with higher price but still highly demanded (differentiation strategy).

Porter's framework uses value chain as a tool for companies to decide their unique value of competitive advantage (either it has existed or it is still a potential). He argued that the source of competitive advantage could not be detected only by examining a firm as it is. Instead, that firm should be dispersed as a series of activities, and then the competitive advantage could be found in one or more parts of the series. Porter divided activities into two types: primary activities which contribute directly in adding value, and support activities which are indirectly contributive.

In Porter's framework, the concept of value chain is not related with the idea of physical transformation. He introduced an idea where competitiveness was not exclusively related to production process. The competitiveness of a business can be analyzed by examining value chain, which contains design, inbound logistics, operation, outbound logistics, market, sales, services and support activities such as strategic planning, human resource management and $R \& D$ (Research and Development).

Therefore, the concept of value chain based on Porter's framework has a strict application. Consequently, the main purpose of value chain analysis is to support decision makers in formulating strategies. For instance, a value chain analysis of a supermarket in Europe shows that its competitive advantage is on providing local fresh fruits and vegetables. This finding can be good information for the supermarket to develop the business right on target. The management team can broaden the network between supermarket

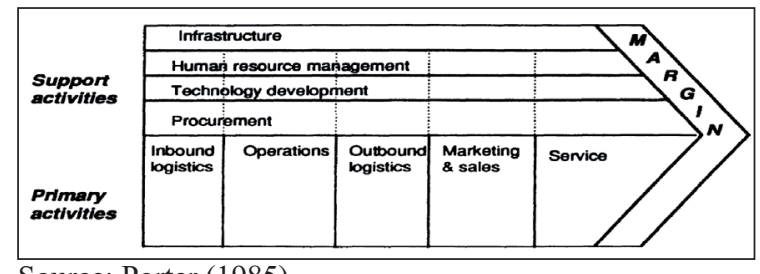

Source: Porter (1985)

Figure 1. Porter's Value Chain and local fruit and vegetable farmers and make advertisements promoting the advantages of fresh food.

The benefit of Porter's model is to identify some primary activities and support activities, both of which, commonly exist in the business sphere. Value chain only looks at some activities, which cause a firm to create value; hence, the Porter's model aims to simplify the analysis (Siddik, 2010).

Another approach to find competitive advantage is the concept of industry value chain system (see Figure 2). The diagram below shows five different activities within the industry value chain or value system. Instead of limiting the analysis only in one firm, all activities within the firm are considered as parts of big activities cycle, which are called "the value system". This comprises activities which happen in all related companies, from producers until the distribution to consumers. This concept is wider than value chain analysis with broader approach.

\section{B. The Value-Added Analysis}

Value-added is the amount by which the value of a commodity is increased at the stage of processing, distribution or storage of its production. In the processing, value-added refers to a difference between the value of a product with raw materials and others, excluding the value of labor (Hidayat, Marimin, Suryani, Sukardi, \& Mohamad, 2012). Meanwhile, the margin is the difference beween the values of a product and the price of raw materials. The margin uses production factor components such as labors, other inputs and retribution for raw material distributors.

Hayami (1987) argued that there were two ways to calculate value-added: one for processing, the other for marketing. There are factors which affect value-added, categorized into two types: technical factor and market factor. The technical factor consists of production capacity and uses raw materials and labors; meanwhile market factor consists of output price, labors wage, raw materials price and other input values.

The distribution of value-added is highly correlated with technology which is applied in 
the processing, labors quality and raw materials. Choosing labor-intensive technology, for instance, has a consequence that budget for labors will be bigger than the firm's profit. On the other hand, choosing capital intensive will make the budget for labors smaller. Their salary depends on their performance. If conversion factor of raw materials into finished products changes, raw materials quality or technology will follow the change (Sudiyono, 2004).

Making value-added is a part of innovation process and product diversification. Innovation is expected to stimulate value-added of product. Innovation is also considered a socio-economic accomplishment in inventing a new way or a new combination of old ways to transform input into output to become a breakthrough in use-value or value of benefits and the monetary value or price (Fontana, 2011).

\section{RESEARCH METHOD}

\section{A. Stages of Research}

To obtain the aim of this study, the research started from value chain survey, mapping (product flow diagram), identifying problems, finding solution and follow up plan, to giving recommendation of value chain reinforcement. Systematically, the stages of this study are depicted on Figure 3 below.

Moreover, this study also aims to identify and analyze how value-added is made in each stage of every product in the oil palm-cattle integration program.

\section{B. Data Processing and Analysis}

Data in this study were processed with tabulation of simple matrix by using Microsoft Office Excel. For the analysis, it used descriptive statistics with Porter's value chain and Hayami's value-added calculation.

We identified five groups of farmers as respondents, scattered in 3 districts of Pelalawan: Karya Lestari group and Usaha Mulia group in Kerumutan District; Sido Rukun in Pangkalan Lesung District; Balacan Putih group and Tunas Harapan group in Langgam District.

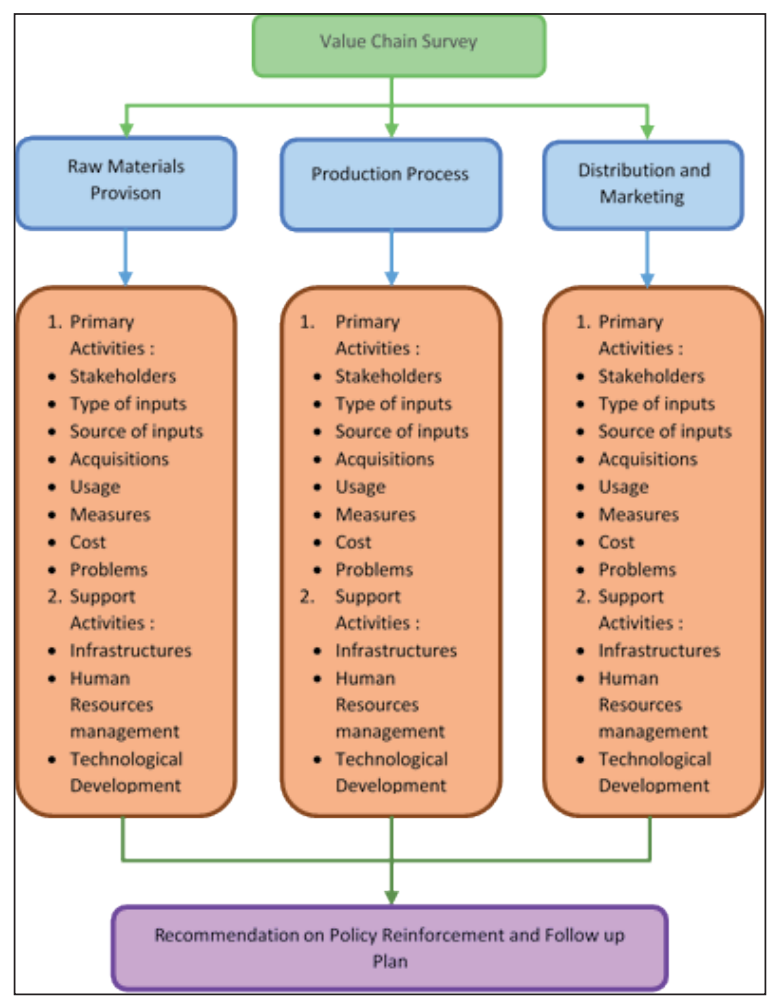

Figure 2. Stages of research

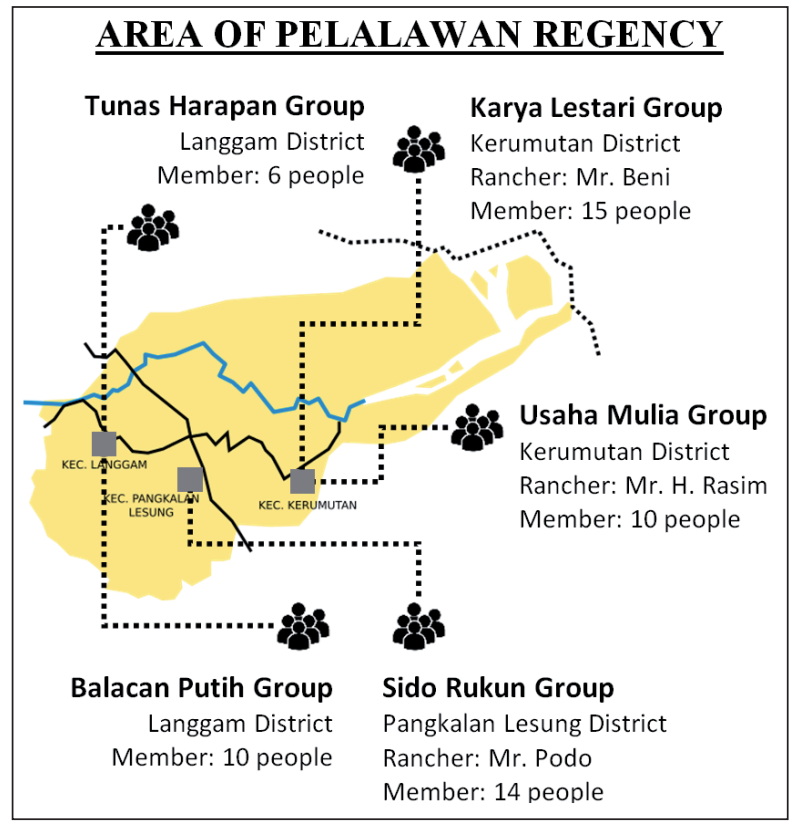

Figure 3. Map of Farmer Groups Distribution in Pelalawan Regency 
We also interviewed and collected data from 2 oil palm companies which were involved in value chain of oil palm-cattle integration: PT Barito and PT Gandaerah Hendana. Both of these companies sold palm kernel meal, which was used to make fodder by farmers in Kerumutan District.

The governments at several levels were also involved in the value chain as supportive stakeholders. At regional level, there was the local government of Pelalawan, represented by the Local Planning Agency (Bappeda), Animal Husbandry Department, and Forestry Department. BPPT or Agency for the Assessment and Application of Technology as a state government agency had come to assist techno park development in Pelalawan Regency, including the integration of oil palm-cattle program.

\section{RESULT AND DISCUSSION}

Based on the survey of several groups of farmers in Kerumutan, Pangkalan Lesung, and Langgam District, we found some data related to the development of the integration program. There were 5 variants of product which were fodder, solid manure, liquid organic fertilizer, biogas, and beef cattle. We collected some data such as the turn over, value-added (profit), value-added ratio and employment data of each group.
To identify the big picture of the program, we make an industry value chain of oil palmcattle integration products (Figure 4). This industry value chain shows inputs, outputs and services which are arranged by many actors. It is a complex process where businesses buy products from suppliers and sell them to customers who then either sell the product as it is, or use it to create another product or service to trade in another form. The process runs until it serves end-users. This creates a value chain (or a value system) of suppliers and customers in an industry processes. The industry value chain of the integration program is shown in Figure 7. We will explain the value-added and value chain of each product in details in the next section.

Because of the straight forward process of value-added of each product, we are not able to draw the industry value chain in every product analysis, instead we show only the average firms value chain. The other reason is there are only a few actors involved in the process as most activities are still handled by one actor (groups of farmers themselves). For instance, fodder is basically the spin-off industry of the ranch as their main product is the beef-cattle. Hence, from collecting inputs to selling the products, those are all handled by the same farmers.

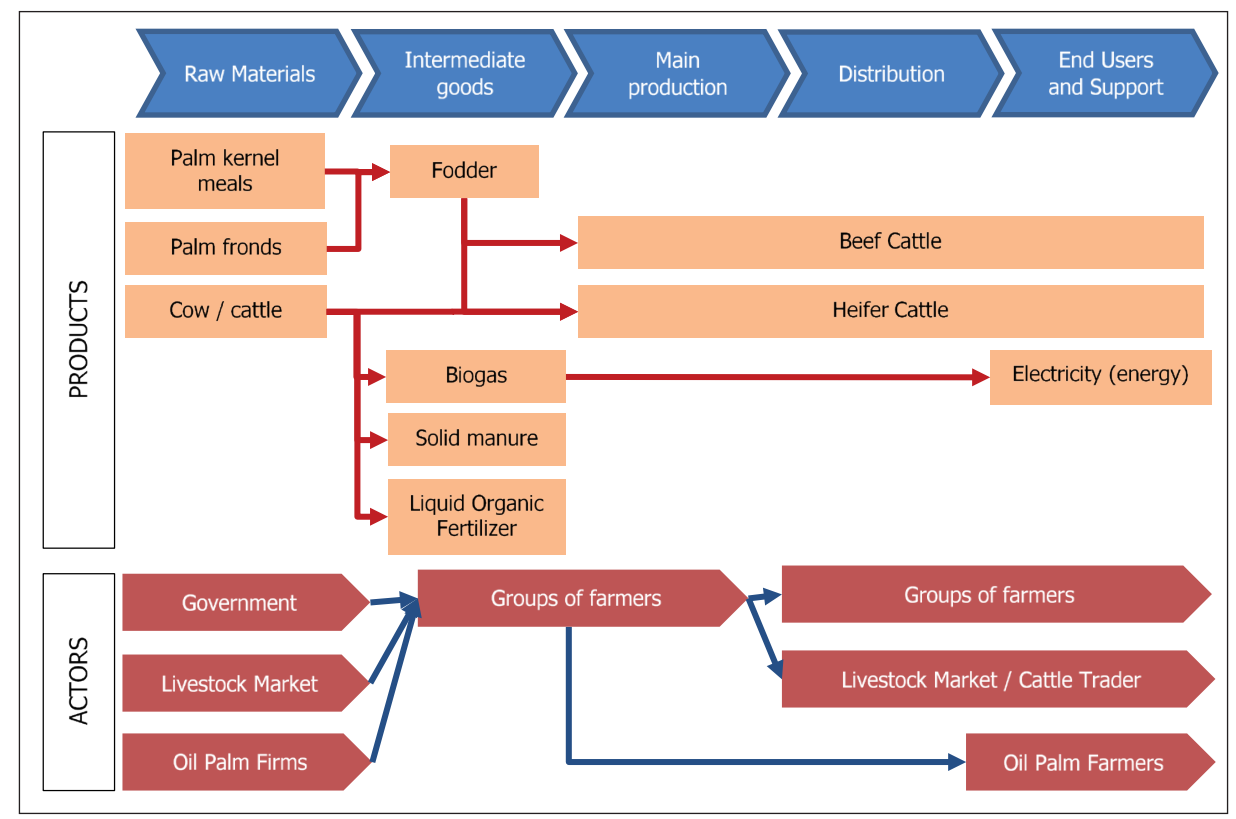

Figure 4. The Industry Value Chain of Oil Palm - Cattle Integration 


\section{A. Fodder Value Chain Analysis}

Fodder gives benefit as nutrition for cattle. To enhance efficiency of fodder cost, groups of farmers in Pelalawan have used the waste of oil palm firms and oil palm trees in their private estate. Palm oil sludge and palm kernel meal are the general ingredients they use.

However, each farmer has their own preference of ingredients to make fodder. Some only use forage grasses, but some mix forage grasses with palm kernel meals and palm fronds, also other additional ingredients if needed (Appendix $1)$.

All ingredients are processed with a machine. First, palm fronds, palm kernel meals and rice bran are chopped with grass chopper machine, then the chopped particles are mixed with baking soda, molasses and solid decanter to make fodder more concentrated using a mixer. Thereafter, the mixture is left and stored for about 2-3 weeks in airtight containers. After the fodder looks concentrated, it is packaged and distributed to some farmers.

The cost for production process consists of raw materials purchase, labor, and operational tools. In the group of farmers in Kerumutan, as a sample, the total cost per month to produce fodder is $\mathrm{Rp}$ (Indonesian Rupiah) 4,884,250. This saves budget for feeding instead of purchasing from other sources which is usually more expensive. Based on average market price in 2014, fodder price was about Rp2,000 per kg.

Mixture-made fodder is only distributed to farmers within the group. The small volume of supply which was less than demand is the main reason why its distribution was still limited at the time the survey was conducted. Appendix 1 shows the detailed value-added of Karya Lestari Group (the only one which produced fodder at the time of this research). The calculation excludes labor cost for 1 month.

The support activities of fodder production have not done well. For instance, supporting industries for some additional ingredients has yet to exist, thus farmers must purchase or order them to colleague in Java Island. In technology development activity, they only had one chopper machine, which was not enough. As comparison,
Karya Lestari is able to produce concentrated fodder for $1,500 \mathrm{~kg}$ every month while there are 78 cattle needing $780 \mathrm{~kg}$ of fodder to eat every day.

\section{B. Solid Manure Value Chain Analysis}

Solid manure is composed from cattle waste or dung instead of cattle urine, which is used for making liquid organic fertilizer. This fertilizer gives benefit since it recycles cattle dung and reduces the cost for fertilizing oil palm plantation.

The ingredients list to make solid manure is mentioned in Table 2. Cattle's solid dung is the predominant material and produced from the farm. Other materials are obtained from purchase, even from outside Pelalawan. Each cow produces dung each day for about $2.5 \mathrm{~kg}$.

The process to produce solid manure is quite simple and only takes 14 days, maximum. Based on Karya Lestari Group explanation, production process only needs the following tools:

1) Manure storage bin (locals say Rumah Kompos or Compost House), worth Rp40,000,000

2) Chopper machine to chop cattle dung, worth Rp24,000,000

It needs 1-2 labors to run the production process. Usually, they also work to raise cattle (including feeding) and to produce other products from ranch. There is no special ability required for workers. Salary for each person varies from Rp2,000,000 to Rp3,500,000 per month (about USD 150 to 250) for doing all the jobs in production process and raising cattle in the ranch.

One of the obstacles in producing solid manure is the imbalance between supply production and demand. It can potentially be overcome by providing more technology and tools to increase production.

Solid manure is distributed and sold only to oil palm farmers in Pelalawan without brokerage. The farmers as producers usually distribute the products by their own vehicles. However, it is possible if buyers come to visit home depots, located near cowshed, and purchase on site.

In period of raising beef cattle, the sale of solid manure gives the highest profit among other products. On average, cattle farmers obtain valueadded of solid manure for about $79.25 \%$. 


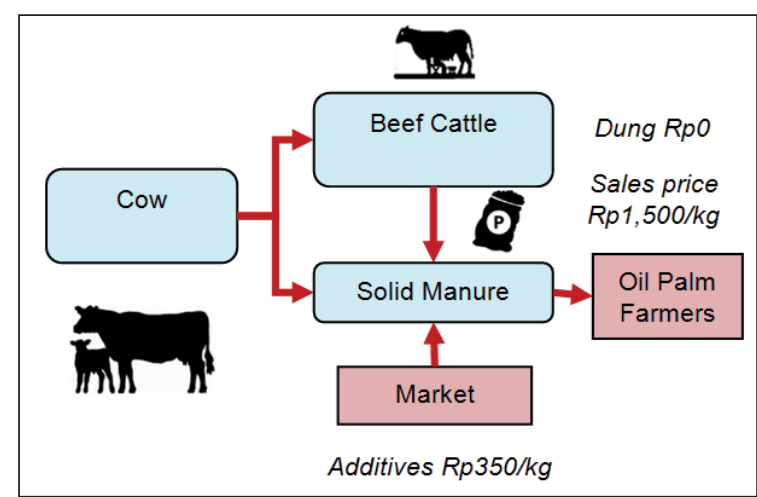

Figure 5. Value-added of Solid Manure

The highest gross profit for solid manure sales is achieved by Karya Lestari Group which earns $\mathrm{Rp}$ 9,360,000 per month. The second highest is Usaha Mulia Group which earns Rp $6,442,500$ per month.

Appendix 2 shows the detailed value-added of solid manure. The calculation excludes labor cost for 1 month. Production of solid manure has not yet had support activities, such as supporting industries. Moreover, development of the technology is still lacking, and many farmers wanted a chopper machine to ease the chopping process for dry raw cattle dung.

\section{Liquid Organic Fertilizer Value Chain Analysis}

This product is similar with solid manure, but it uses cattle urine as the primary material. The ingredients are as follows: cattle urine, bio activator (EM4), and other optional additives such as molasses, shrimp paste, or ginger. Farmers pay nothing on cattle urine since they can get it from their own farms. On average, a cow produces 5 liters of urine per day. Farmers only need to use their money to purchase bio activator with the price of $\mathrm{Rp} 25,000 /$ liter.

To get raw materials, there are some obstacles such as the lack of water source provided and not enough of urine drums/containers. Consequentially, cattle urine cannot be fully processed into fertilizer and are wasted instead.

The making process of liquid organic fertilizer is quite simple as farmers simply need to store the urine in the air tight plastic container until it gets fermented. Tools needed are as follows:

1) Airtight plastic container worth $R p 1,300,000$ each

2) Pump, to drain urine, worth Rp3,000,000

Based on the survey to Karya Lestari Group and Balacan Putih Group, they said that they only needed 1-2 labors in production process, while the others did not. Each labor earned salary for about Rp2,500,000-4,000,000 per month (USD 175-280) for doing all the jobs (besides making the fertilizer).

Liquid organic fertilizers are packaged into 20 and 30 liters jerry cans and stored in the group's home depot. However, Sido Rukun Group made a breakthrough by providing delivery service to consumers. There has not been brokerage for this kind of product yet.

Sales price for the liquid organic fertilizer is Rp600 at the lowest (Balacan Putih Group) and Rp2,000 at the highest (Karya Lestari) for each litre. Promotion and marketing are still done by word-on-mouth scheme among oil palm farmers.

The liquid organic fertilizer gives the highest value-added among other products in the integration program. Farmers can get average value-added for about $81 \%$ from selling the product. The highest is earned by Karya Lestari with Rp14,470,000 per month, or equal to $90.44 \%$. Nevertheless, by percentage alone, the highest value-added is earned by Mr. Darsono from Sido Rukun, with 92.06\%. value-added. This impressively high value happens because farmers pay nothing to get the urine as primary

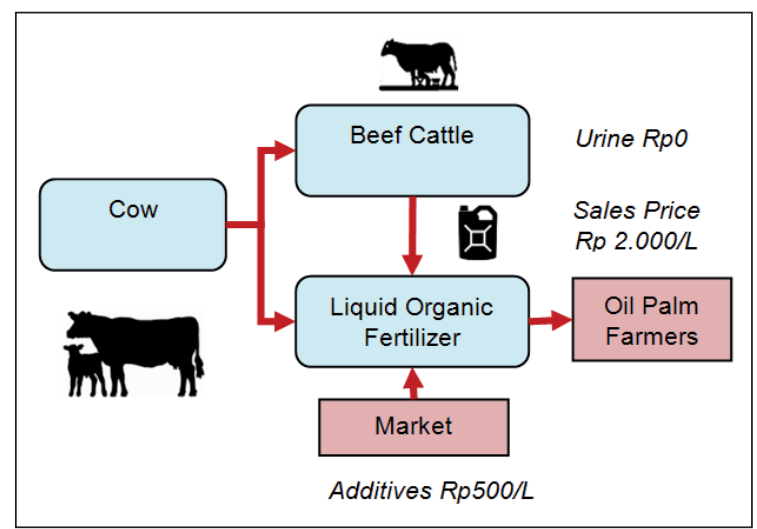

Figure 6. Value-added of Liquid Organic Fertilizer 
ingredient. However, a farmer namely Mr. Agus from Sido Rukun still gets negative value-added $(-25 \%)$ because he is still hit by high operational cost which fails to reach the break-even point.

The profit margin (excluding operational cost) of liquid organic fertilizer has the highest value at Karya Lestari Group which approaches Rp14,560,000 per month. This happens because of the enormous amount of their cattle (78 cattle) which means a large amount of urine is produced each day. Components of value-added of the liquid organic fertilizer (excluding monthly labor cost) are shown on Appendix 3.

Currently, the chain process of liquid organic fertilizer is still done only by groups of farmers. In technology development aspect, even though it is still considered as a simple technology, fermentation (chemical process) exists in the process.

\section{Biogas Value Chain Analysis}

Cow dung can also be processed as biogas, besides being used as solid manure. Biogas gives benefit for farmers as alternative energy for lighting and as the substitute for liquefied petroleum gas (LPG), which is commonly used for cooking. Biogas is composed of $60 \%$ methane gas, $30 \% \mathrm{CO}_{2}$, and the remaining $10 \%$ mixed from $\mathrm{O}_{2}, \mathrm{H}_{2}$ and $\mathrm{H}_{2} \mathrm{~S}$. Biogas has a caloric value of about $4,800-6,700 \mathrm{Kcal} / \mathrm{m}^{3}$. If compared with pure methane gas $(100 \%)$ whose calorie value is $8,900 \mathrm{Kcal} / \mathrm{m}^{3}$, biogas' calorie is considerably competitive since it can substitute pure methane gas up to $50 \%$. For electricity, $1 \mathrm{~m}^{3}$ of biogas gives power of 6,000 watt-hours, which equals to energy produced by $1 / 2$ litre of diesel fuel. The proper biogas utilization in the integration program of oil palm-cattle can give energy efficiency for oil palm farmers or cattle farmers/ranchers.

For producing biogas, most of the ingredients are cow dung. There is also no other cost since farmers only need to reuse cow dung from their own cattle (Appendix 4). Farmers do not find any significant obstacles in processing biogas because they believe the process is quite simple.

Biogas is produced using biogas digester to make fermented cow dung produce energy. Until this study was conducted, the capacity of digester in Kerumutan, Langgam, and Pangkalan Lesung was only $4-5 \mathrm{~m}^{3}$ per month.

The production process of biogas with digester takes 14 days until it is ready to be used. The process is quite simple. First, cow dung is stored in sealed digester tank until it releases methane gas due to fermentation. The small capacity of digester unfortunately limits the amount of dung which can be stored. Until recently, farmers were only able to store $1,000 \mathrm{~kg}$ of dung (even though each month cattle produce $3,750 \mathrm{~kg}$ of dung), so they must store dung every three days. The volume of $4 \mathrm{~m}^{3}$ biogas per month equals to 24,000 watt-hours for electricity use or four times a single three-kilogram LPG cylinder for cooking.

The biogas production process needs only one labour per month. Consequently, the biogas production has almost no cost since the digester is also given by government grant. Even though biogas does not cost anything, biogas does not make financial profit either. It is used by farmers for household lighting and cooking.

The biogas is currently used for houses of farm labors. Since using biogas, they don't need LPG anymore. In the past, they spent 4 threekilogram LPG cylinders per month. Therefore, today they can save between $\mathrm{Rp} 75,000-120,000$ every month.

Since it does not need additional ingredients, the value-added of biogas is very high. Even though they are not for sale, with costless cow dung collection, farmers can save money from electricity and gas up to Rp250,000 per month. Almost all groups which use biogas as fuel/gas substitution get $100 \%$ value-added from biogas,

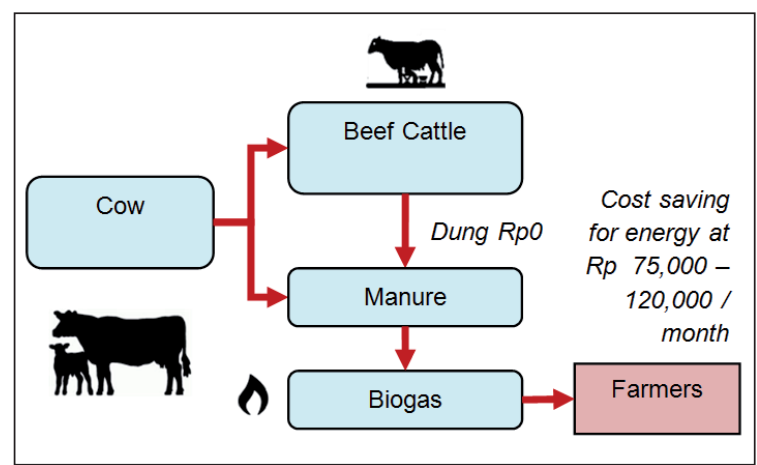

Figure 7. Value-added of Biogas 
except Mr. Toto and Mr. Slamet from Sido Rukun Group, because of the high production cost they require. Total ratio of value-added from biogas is $74.29 \%$ with total efficiency value for fuel and gas dependency is Rp945,000 per month. Appendix 4 shows the detailed value-added of biogas. The calculation excludes labor cost for 1 month.

Support activity which is urgent to be improved is technology development. Current digester capacity needs to be increased from 4 $\mathrm{m}^{3}$ to $15 \mathrm{~m}^{3}$ to ensure that all produced cow dung can be efficiently processed into biogas.

\section{E. Beef Cattle Value Chain Analysis}

Beef is the primary product sought by every group of farmers. To get the beef product, farmers need to breed cattle either as breeding livestock or steer. Farmers have expenses, such as for fodder, for medicines, and for cattle's periodic medical checkup to veterinarian. To make this ranch sustainable, they need breeder cow (not used as beef) to breed new calves. The type of cattle also varied, such as Bali cattle (banteng), Limousine, Simmental and Ongole crossbred.

Cattle in Pangkalan Lesung District and Kerumutan District are derived from purchasing and government aid. One cattle for breeding was purchased at Rp6,000,000. However, because cattles are considered non-disposable material and non-once sale or consumption product, they can be categorized as asset. Different with both districts, farmers in Langgam received all their cattle from government grant namely MP3KI (Masterplan on Fostering and Broadening Poverty Reduction Program) in 2014.

The husbandry process of cattle takes several times in every farm. For instance, farmers in
Kerumutan, which have started husbandry since several years ago, need 30 months to raise beef cattle. Farmers in Pangkalan Lesung need 6 until 24 months. Meanwhile, farmers in Langgam do not have the data yet because none of the cattles has been sold (they started the husbandry business in 2014).

Tools for raising beef cattle are similar with fodder production process such as grass chopper machine, lawn mower, sickle, cleaver, and cowshed. Farmers also do grazing for cattle to minimize fodder production cost and give space to cattle outside cowshed (in order to reduce cattle stress after being caged in cowshed for almost a day). Cattle are usually grazed on the oil palm estate area owned by farmer group or on the public field.

Labors for cattle husbandry only exist in farmer groups in Kerumutan, which are Usaha Mulya and Karya Lestari and Balacan Putih in Langgam District. Usaha Mulya has a labor with salary Rp1,200,000 per month (approximately USD100) to raise 14 cattles (producing solid manure and liquid organic fertilizer), meanwhile Karya Lestari has 3 labors with salary of each Rp3,500,000 per month (USD 250) to raise 78 cattles (producing solid manure, liquid organic fertilizer, biogas, and fodder). Balacan Putih group in Langgam District has 2 labors with salary of each Rp4,000,000 per month (USD 275) to raise 12 cattles.

Cattles ready for sale (steer, heifer or cow) are traded to slaughterhouse, other farmers, or livestock markets. However, instead of being brought by farmers to those locations, cattles are usually bought directly by buyers or traders on the husbandry so there is no shipping cost.

Table 1.

Value-added Calculation on the Integration of Oil Palm-Cattle Program (per annum)

\begin{tabular}{|c|c|c|c|c|c|}
\hline Variabel & Fodder & Beef Cattle & Solid Manure & Liquid Fertilizer & Biogas \\
\hline Sales volume & $61,932 \mathrm{~kg}$ & 44 head & $270,600 \mathrm{~kg}$ & $174,000 \mathrm{~L}$ & $98,280 \mathrm{~L}$ \\
\hline Sales price (RP) & $2.500 / \mathrm{kg}$ & $9,636,364$ & 1,217 & 2,200 & - \\
\hline Turnover & $45,000,000$ & $289,500,000$ & $348,510,000$ & $297,840,000$ & $16,140,000$ \\
\hline Value-added & $(1,800,000)$ & $52,098,150$ & $264,570,000$ & $240,780,000$ & $11,340,000$ \\
\hline Value-added Ratio & $-4 \%$ & $18 \%$ & $76 \%$ & $81 \%$ & $70 \%$ \\
\hline
\end{tabular}




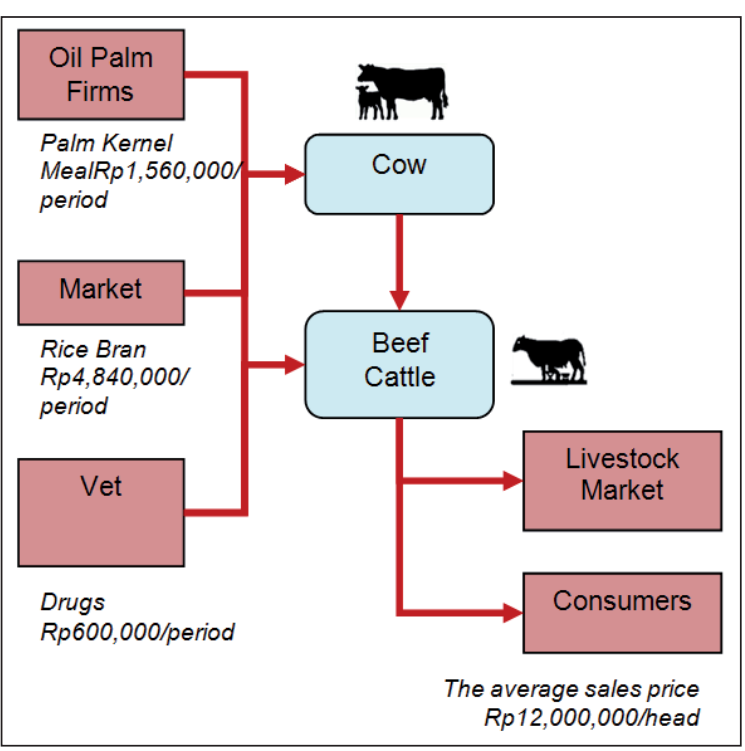

Figure 8. Value-added of Beef Cattle

Farmers in Pelalawan sell each cow between Rp8,000,000-15,000,000 (USD 585-1100) depending on the weight. The average weight of sold oxen or steers (since the cows are preferably being kept for breeding) is up to $300 \mathrm{~kg}$ each. Promotion is only done with word-on-mouth. Based on the survey, farmers in Kerumutan District sold about 20 cattles (during the period of 2013-2015), the most sales in the area. Other farmers were only able to trade 1-2 cattle because they were still relatively new in cattle farming (last 6-24 months).

The average farmer earns profit from cattle sales for about Rp13,663,283 or about USD 1000 (excluding operational cost) with the average breeding period of 19 months. Meanwhile, total value-added (turnover) of the cluster is Rp28,180,952 or USD 2062 per period of breeding (19 months). This shows that cattle breeding or farming does not contribute much profit to farmers (Soeharsono \& Sudaryanto, 2011). Nevertheless, profit can be earned if the period of breeding lasts longer (up to 30 months). Value-added ratio of beef cattle, compared with solid manure and liquid organic fertilizer, is quite low, which is only valued at $18 \%$.

The highest value-added (minus total production cost which is including material cost) is earned by Usaha Mulya Group at Rp 18,898,000 per 30 months, or approximately Rp 629,933 per month. Appendix 5 shows the detailed value- added of beef cattle. The calculation excludes labor cost for 1 month.

Support activities of beef cattle can be recognized from technology development done by farmers. They have used technology in palm kernel meal chopping process which is much better than forage grasses. About $55 \%$ of respondents admitted that they were given some training on cattle breeding, such as on processing fodder, cattle health assessment and cattle dung and urine utilization.

\section{F. Value-added Comparison of All Five Products}

The calculation shows that between five products from the integration of oil palm-cattle program, solid manure gives the highest value-added at Rp264,570,000. Unfortunately, the big value is not as much as the value-added ratio. This happens because many farmers are only producing without trading them, so profit could not have been calculated yet. Otherwise, all farmers have produced and traded the liquid organic fertilizer, so we can see the profit from this product.

The highest value-added ratio is reached by liquid organic fertilizer at $81 \%$. That value is affected by the low production cost and not many materials needed to produce the fertilizer. Farmers only need cattle urine from their own cattle.

The calculation also shows that biogas development is the most potential among other products. It is because the high value-added ratio produced from biogas is up to $70 \%$. Even though its usage is still limited among farmers' households, three groups which got benefit (Sido Rukun, Karya Lestari and Tunas Harapan) could save electricity and fuel cost up to about Rp1,345,000 per month. This opportunity should be developed further to reap benefit from biogas commercially. The government support is expected to maximize the utilization of biogas in the region.

Figure 9-10 show data of total income and value-added in the integration program. From the data below, the highest turnover from the integration program is reached by solid manure at Rp348,510,000 per annum, followed by liquid organic fertilizer at Rp297,840,000 per annum, 


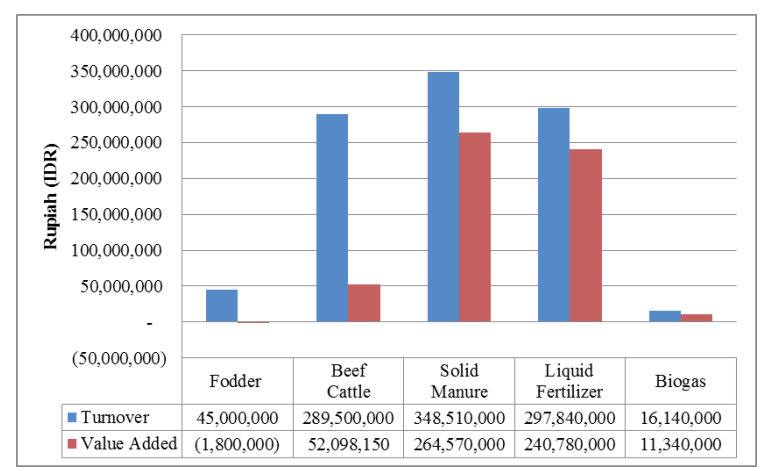

Figure 9. Turnover and Value-Added of Products from The Integration Program (in a year)

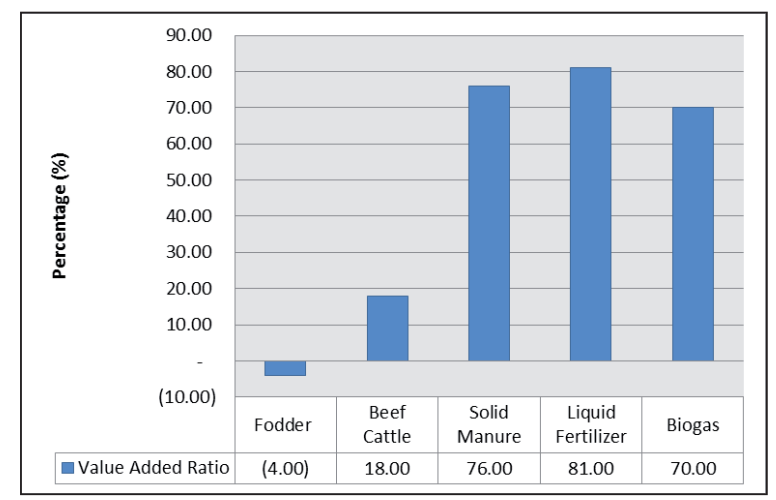

Figure 10. Value-added Ratio of Products in The Integration Program beef cattle Rp289,500,000 per annum, fodder Rp45,000,000 and biogas Rp16,140,000 per annum.

The highest value-added came from solid manure at Rp264,570,000 per annum. On the contrary, fodder has negative value-added at $\mathrm{Rp} 1,800,000$ per annum, which means it gives loss to farmers. This is because many materials in producing fodder are still imported such as rice bran and molasses. The highest value-added ratio is reached by liquid organic fertilizer at $81 \%$.

\section{G. Relation of Actors}

Although the focus of this study is discussing value-added and value chain of every product in the oil palm-cattle integration program, we also want to draw how actors in this process can relate to each other. In the theoretical part, we discussed the network and intertwined works between academia, business or industry, government, and public. In Figure 11, we drew a picture of oil palm-cattle integration cluster to show the role of each actor. Understanding the role of actors can help us to arrange the reinforcement programs in

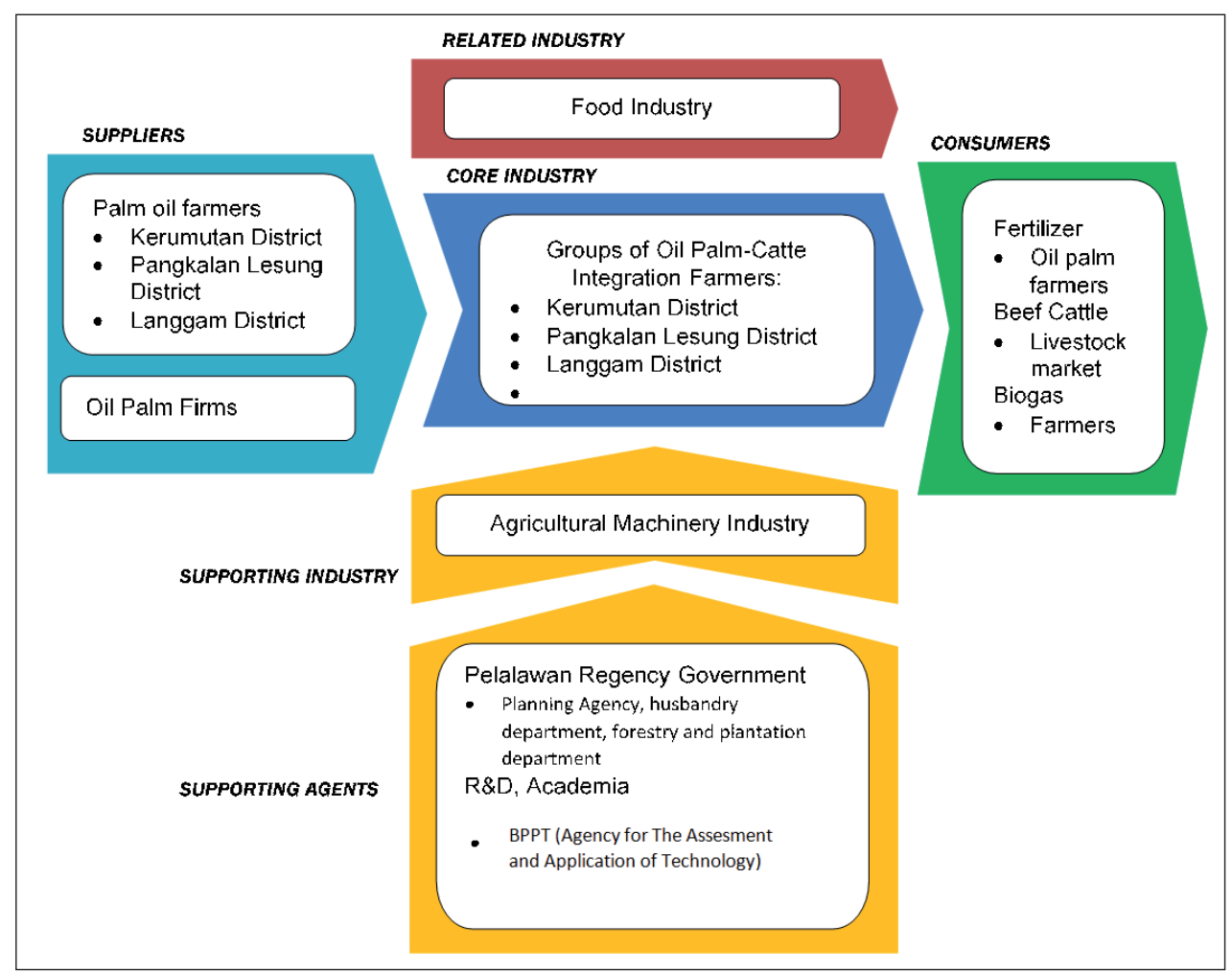

Figure 11. The Cluster of Oil Palm - Cattle Integration. 
the next section to remind us that the programs have accommodated all actors in the future.

\section{H. Obstacles from the Integration Program}

The development of integration program encounters many obstacles, such as:

1) Based on survey to stakeholders (farmers and regency government), recently, there were not many oil palm firms interested in implementing the integration program. Implementation is currently only done by farmer groups in Pelalawan Regency.

2) Integration of cattle and oil palm plantation allegedly affects oil palm tree to be infected by Ganoderma zonatum which has caused butt rot.

3) Process of implementation can cause solid compaction in the oil palm plantation area.

4) Cattle farmers and oil palm farmers have not had access to get oil palm firm's by-products such as palm kernel meals and other solid/ liquid waste as fodder resource.

5) Farmers still lack of knowledge about the benefit of the integration program.

6) Access to market for selling products from the integration program is still limited, therefore enthusiasm of farmers in Pelalawan is still rather low.

7) Infrastructures owned by farmer groups to develop business form in the integration program is still lack in both quantity and quality.

\section{Reinforcement Programs}

Based on the result of five products survey from the integration program, this study attempts to arrange reinforcement programs which are expected to contain suggestions to all stakeholders, such as academia, business, government, and community in improving competitiveness of cluster of oil palm-cattle integration in Pelalawan, as follows:

\section{Reinforcement Programs for Fodder}

1) Make a business entity such as the cooperation for farmers in stocking fodder
2) Encourage the growth of concentrated fodder producers

3) Train farmers to be able to modify chopper machine

4) Conduct a training on product quality improvement

5) Make an agreement with funding institutions/ cooperation to provide funding for farmers or related SMEs

6) Disseminate the SME funding resource such as KUK and KUR Program from various national banks

7) Make an agreement with $R \& D$ institutions such as Technology High Schol of Pelalawan (ST2P), Agency for The Assessment and Application of Technology (BPPT), Riau University UNRI, and Riau Islamic Institute (IAIN Riau), to improve technology development in fodder processing

8) Conduct a competition of innovation among farmers

9) Give incentives for farmer groups who successfully innovate in making fodder

\section{Reinforcement Programs for Solid Manure}

1) Hold facilities and tools to make manure

2) Set manure quality standard

3) Disseminate the standard

4) Disseminate the benefit of solid manure

5) Buildcooperation with funding institutions to give initial capital

6) Build an entity of business such as cooperation for manure sales

\section{Reinforcement Programs for Liquid Organic Fertilizer}

1) Set the liquid organic fertilizer quality standard

2) Disseminate the standard

3) Add a label of nutrient composition on the pack

4) Make a cooperation with funding institutions to give initial capital

5) Build an entity of business such as the cooperation for fertilizer sales 


\section{Reinforcement Programs for Biogas}

1) Disseminate the benefit of biogas as the waste (dried dung) can also be processed as manure (double benefits)

2) Explain the usage of biogas to generate power

3) Analyze the market potential of biogas waste.

\section{Reinforcement Programs for Beef}

1) Disseminate the fodder calorific value standard for cattle health

2) Disseminate the composition of ingredients needed to make fodder to reach the standard of calorific value

3) Conduct a discussion with farmers about good procedure of cattle farming

4) Disseminate the technology of artificial insemination on sexing

5) Build the center for cattle breeding in Pelalawan

6) Revitalize the livestock market

7) Educate farmers about cattle health

8) Build a business entity such as the cooperation to provide veterinary drugs

9) Conduct a training on cattle health care to have a small cadre of local veterinarian

10) Provide infrastructures to complement the function of slaughterhouse and livestock market

11) Make a cooperation with funding institutions to give initial capital.

\section{CONCLUSION}

Among the five products from the oil palm-cattle integration program, the liquid organic fertilizer and solid manure are surprisingly more profitable than the primary product of husbandry: the beef. Nonetheless, both products are highly dependent on the beef cattle existence. In other words, if the business of manure and liquid organic fertilizer are not profitable, the business of beef cattle will also fail. Hence, the quality and quantity of manure and liquid organic fertilizer should be maintained to make the integration program runs well.
Although farmers get a lot of benefits from the implementation of the integration program, some obstacles are still found and need to get attention. Otherwise, the program will lose trust from participating oil palm firms.

The cluster of oil palm-cattle integration is considered as the best practice to develop local economic in Pelalawan. The primary concept in cluster development is to build a network between all stakeholders within the cluster. Reinforcement programs, which also involved all stakeholders, are expected to improve the competitiveness of the cluster and the prosperity the cattle farmers.

Hence, to ensure that the cluster of oil palm-cattle integration provide benefit and economic impact to all actors, the following are some recommendations which can be the primary programs in developing the cluster.

1) Incentive or grant program to support infrastructure provision such as tools and cowshed

2) Socialization to cattle farmer groups, oil palm farmer groups, and oil palm firms about the benefit of the integration program

3) Improvement on digester capacity for biogas production which considers each farmer's need

4) Establishment of business entity e.g. the cooperation to coordinate all activities on the integration program, such as marketing, raw materials provision, and veterinarian drugs provision, etc.

\section{ACKNOWLEDGMENT}

This research was funded by BPPT in 2015 as part of techno park development program in Pelalawan Regency. The research result was submitted and presented to Regional Development Planning Agency (Bappeda) of Pelalawan and Animal Husbandry Department of Pelalawan as the users. The authors would like to express the biggest appreciation for all who support this study, as follows: Deputy for Technology Policy Assessment, Director of The Center for Technological Innovation Policy Assessment (PPKIT) and Pelalawan Government which was supporting authors to collect data for the research. 


\section{REFERENCES}

ACIAR. (2012). Membuat rantai nilai lebih berpihak pada kaum miskin. [Make a value chain more pro-poor]. Canberra: Australian Centre For International Agricultural Research.

Andri, K.B. \& Stringer, R. (2010). Panduan pedoman pelaksanaan penerapan VCA (analisis rantai nilai) untuk staf peneliti BPTP dan BBP2TP. [Guidelines on Implementation of VCA (Value Chain Analysis) for Research Staff of BPTP and BBP2TP]. Bogor: Badan Litbang Pertanian, Kementerian Pertanian.

BPS Kabupaten Pelalawan. (2013). Kabupaten Pelalawan dalam angka 2012. [Regency of Pelalawan in figures 2012]. Pelalawan: BPS Kabupaten Pelalawan

Daryanto. A. (2011, February). Nilai tambah peternakan melalui agroindustri. [Value Added Animal Husbandry Through Agroindustry]. TROBOS, 137.

Fontana, A. (2011). Innovate we can! Manajemen inovasi dan penciptaan nilai. [Innovate we can! Innovation management and value creation]. Jakarta: Cipta Inovasi Sejahtera.

Gunawan, A., Sitompul, D.M., \& Manurung, B.P. (2004). Sistem integrasi sapi kelapa sawit (SISKA) pola inti plasma. [Palm-cow integration system (SISKA) core plasma pattern]. Bengkulu: Balai Pengkajian Teknologi Pertanian, Pusat Penelitian dan Pengembangan Sosial Ekonomi Pertanian, Badan Penelitian dan Pengembangan Pertanian.

Hayami, Y. (1987). Agricultural marketing and processing in upland Java. Bogor: CGPRT Centre.

Hidayat, S., Marimin, Suryani, A., Sukardi, Mohamad, Y. (2012). Modifikasi metode hayami untuk perhitungan nilai tambah pada rantai pasok agroindustri kelapa sawit. [Modification of hayami methods for calculation of value added on supply chain of palm oil agroindustry]. Jurnal Teknologi Industri Pertanian, 22(1), pp. 22-31.
Kaplinsky, R. (1999). Globalization and unequalization: What can be learned from value chain analysis? Journal of Development Studies 37(2), pp. 117-146. https://doi.org/10.1080/713600071

Kaplinsky, R., \& Morris, M. (2001). A handbook for value chain research (Vol. 113). Ottawa: IDRC.

Kementerian Pertanian. (2015). Outlook komoditas pertanian sub sektor peternakan daging sapi. [Agricultural commodities outlook of beef husbandry sub sector]. Jakarta: Pusat Data dan Sistem Informasi Pertanian Sekertariat Jendral Kementerian Pertanian.

Siddik, M. (2010). Pengembangan rantai nilai komoditas di Provinsi Nusa Tenggara Barat [Development of gaharu commodity value chain as an alternative for poverty reduction in West Nusa Tenggara Province]. Agroteksos, 20(2-3)

Porter, M. E. (1985). Competitive advantage: Creating and sustaining superior performance. New York: Free Press.

Situmorang, B., Edwina, S,. \& Maharani, E. (2015). Adopsi inovasi teknologi petani kelapa sawit terhadap sistem integrasi sapi - kelapa sawit (SISKA) di Kabupaten Pelalawan. [Adoption of technological innovation of palm oil farmer on integration system of cow-palm oil (SISKA) in Pelalawan Regency]. Jom Faperta, 2(1). Retrieved from http://jom.unri.ac.id/index.php/ JOMFAPERTA/article/download/5470/5349

Soeharsono, B. Sudaryanto. (2011). Inovasi pembibitan ternak sapi potong berbasis sistem integrasi tanaman - ternak pada lahan irigasi di Yogyakarta. [Innovation on crop-livestock integration system-based cattle breeding livestock in irrigation land in Yogyakarta]. In Prosiding Lokakarya Nasional Pengembangan Jejaring Litkaji Sistem Integrasi Tanaman-Ternak. Yogyakarta: Balai Pengkajian Teknologi Pertanian.

Sudiyono, A. (2004). Pemasaran pertanian. [Agricultural marketing]. Malang: Universitas Muhammadiyah Malang Press. 
Appendix 1.

Ingredients of fodder

\begin{tabular}{|c|c|c|}
\hline Material & Source & Cost \\
\hline \multicolumn{3}{|c|}{ Kerumutan District } \\
\hline Forage grasses & Field & - \\
\hline Palm fronds & Private estate & - \\
\hline Palm kernel meals & PT Gandaerah Hendana, PT Barito & RP 1,650/kg (Gandaerah). RP 1,300/kg (Barito) \\
\hline Rice/Corn Bran & Market & RP 3,200-3,500/kg \\
\hline Molasses & Java & RP $8,000-15,000 / L$ \\
\hline Baking Soda & Market & RP $25,000-40,000 / \mathrm{kg}$ \\
\hline Soy Pulp & Java & RP $4,000 / \mathrm{kg}$ \\
\hline \multicolumn{3}{|c|}{ Pangkalan Lesung District } \\
\hline Forage Grasses & Swamp & - \\
\hline Palm fronds & Private estate & - \\
\hline Palm kernel meals & Aid & RP $1,600 / \mathrm{kg}$ \\
\hline Rice/Corn Bran & PT Mas & RP $120,000 /$ ton \\
\hline Molasses & Market & $\mathrm{RP} 3,500 / \mathrm{kg}$ \\
\hline Palm fronds & Market & RP $18,000 / \mathrm{kg}$ \\
\hline Mineral Salt & Market & RP $10,000 /$ pack \\
\hline \multicolumn{3}{|c|}{ Langgam District } \\
\hline Forage Grasses & Private Estate & - \\
\hline Palm fronds & Private Estate & - \\
\hline
\end{tabular}

Total production cost (raw material, others, including operational cost) $=\mathrm{Rp} 3,900,000 /$ month

Fodder total production $=1,500 \mathrm{~kg} /$ month

Sale price $=\operatorname{Rp} 2,500 / \mathrm{kg}$

Total turnover $=\operatorname{Rp~3,750,000/month~}$

Margin $=\operatorname{Rp~570,000/month~}$

Negative value-added due to financial loss

Value-added ratio $=-4.00 \%$

\section{Appendix 2.}

Ingredients and Costs of Solid Manure Production

\begin{tabular}{ccc}
\hline Material & Source & Cost \\
\hline Cattle dung & Group's cattle & - \\
\hline Straw & Plantation waste & - \\
\hline Starter & Market & Rp 5.000/L \\
\hline EM4 (decomposer) & Market \& Aid & Rp 20.000/L \\
\hline
\end{tabular}

Total production cost (raw material, others, including operational cost) $=\mathrm{Rp} 6,095,000 /$ month

Solid manure total production $=22,550 \mathrm{~kg} /$ month

Sale price $=\mathrm{Rp} 1,217 / \mathrm{kg}$

Total turnover $=\operatorname{Rp} 29,042,500 /$ month

Margin $=\operatorname{Rp} 25,627,500 /$ month

Value-added $=\operatorname{Rp} 22,047,500 /$ month

Value-added ratio $=79.25 \%$ 


\section{Appendix 3.}

Ingredients and Costs of Liquid Organic Fertilizer Production

\begin{tabular}{lll}
\hline Material & Source & Cost \\
\hline Cattle urine & Cattle & - \\
\hline EM4 (decomposer) & Livestock Market & RP 25,000/L \\
\hline Water & Well & - \\
\hline
\end{tabular}

Total production cost (raw material, others, including operational cost) $=\mathrm{Rp} 4,755,000 /$ month

Solid manure total production $=14,500 \mathrm{~kg} /$ month

Sale price $=\operatorname{Rp} 2,200 / \mathrm{kg}$

Total turnover $=\mathrm{Rp} 24,820,000 /$ month

Margin $=\operatorname{Rp} 21,465,000 /$ month

Value-added ratio $=81 \%$

\section{Appendix 4.}

Ingredients and Costs of Biogas Production

\begin{tabular}{lll}
\hline Material & Source & Cost \\
\hline Cattle dung & Cattle & - \\
\hline Water & Well & - \\
\hline
\end{tabular}

Total production cost (raw material, others, including operational cost) $=\mathrm{Rp} 400,000 /$ month Biogas total production $=$ equals to $5 \times 3 \mathrm{~kg}$ LPG cylinders

Sale price $=$ Not for sale yet

Efficiency per month $=\mathrm{Rp} 1,345,000$

Margin of saving per month $=$ Rp 1,345,000/month

Value-added of saving $=\operatorname{Rp} 945,000 /$ month

Value-added ratio $=70 \%$

\section{Appendix 5.}

Ingredients and Costs of Beef Production

\begin{tabular}{|c|c|c|}
\hline Material & Source & Cost \\
\hline \multirow{2}{*}{ Cow } & Government Grant & - \\
\hline & Livestock market & Rp6,000,000/head \\
\hline \multirow{2}{*}{ Fodder } & Public Field & - \\
\hline & Oil Palm Firms (for palm kernel meal) & $\mathrm{Rp} 1,300 / \mathrm{kg}-1,600 / \mathrm{kg}$ \\
\hline \multirow{2}{*}{ Veterinarian Drugs } & Vet & Rp 150,000 - Rp180,000 /bottle \\
\hline & Local Government Aid & - \\
\hline Immunization & Local Government Aid & - \\
\hline
\end{tabular}

Total production cost (raw material, others, including operational cost) $=\mathrm{Rp} 14,310,579 /$ month

Beef cattle total production $=3-4$ cattle $/$ month

Sales price $=\operatorname{Rp} 9,636,364$ per head

Total turnover $=\mathrm{Rp} 24,125,000 /$ month

Margin $=\mathrm{Rp} 14,310,579 /$ month

Value-added $=\mathrm{Rp} 4,341,513 /$ month

Value-added ratio $=18 \%$ 